\title{
New contributions to two ciliate genera (Ciliophora, Heterotrichea) based on morphological and molecular analyses, with description of a new Gruberia species
}

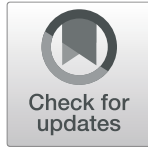

Yong $\mathrm{Chi}^{1+}$, Yuqing $\mathrm{Li}^{1+}$, Qianqian Zhang ${ }^{2,3+}$, Mingzhen Ma', Alan Warren ${ }^{4}$, Xiangrui Chen ${ }^{5 *}$ (D) and Weibo Song ${ }^{1 *}$

\begin{abstract}
Background: Heterotrichous ciliates are common members of microeukaryote communities which play important roles in both the transfer of material and the flow of energy in aquatic food webs. This group has been known for over two centuries due to their large body size and cosmopolitan distribution. Nevertheless, species identification and phylogenetic relationships of heterotrichs remain challenging due to the lack of accurate morphological information and insufficient molecular data.

Results: The morphology and phylogeny of two heterotrichous ciliates, namely Gruberia foissneri spec. nov. and Linostomella vorticella (Ehrenberg, 1833) Aescht in Foissner et al., 1999, were studied using rigorous methods (living morphology, stained preparations, and small subunit rDNA sequence data). Gruberia foissneri spec. nov. is morphologically very similar to G. uninucleata Kahl, 1932, however, it can be distinguished from the latter by having more ciliary rows (about 32 vs. about 20) and macronuclear shape (sausage-shaped vs. ellipsoid). Based on a combination of previous and present studies, an improved diagnosis of L. vorticella is supplied and several taxonomic anomalies are clarified. In addition, phylogenetic analyses based on SSU rDNA sequence data support the generic assignment of these two species.

Conclusions: Modern ciliate taxonomy should be performed by means of detailed living observation, stained preparations and molecular information. For those species that have been reported in previous studies, it is necessary to provide as much useful information as possible using state-of-the-art methods in order to resolve taxonomic anomalies.
\end{abstract}

Keywords: Heterotrichs, Morphology, Phylogeny, SSU rDNA

\footnotetext{
*Correspondence: xiangruichen@126.com; wsong@ouc.edu.cn

${ }^{\dagger}$ Yong Chi, Yuqing Li and Qianqian Zhang contributed equally to this work.

${ }^{5}$ School of Marine Sciences, Ningbo University, Ningbo 315211, China

${ }^{1}$ Institute of Evolution and Marine Biodiversity, and College of Fisheries,

Ocean University of China, Qingdao 266003, China

Full list of author information is available at the end of the article
}

(c) The Author(s). 2020 Open Access This article is licensed under a Creative Commons Attribution 4.0 International License, which permits use, sharing, adaptation, distribution and reproduction in any medium or format, as long as you give appropriate credit to the original author(s) and the source, provide a link to the Creative Commons licence, and indicate if changes were made. The images or other third party material in this article are included in the article's Creative Commons licence, unless indicated otherwise in a credit line to the material. If material is not included in the article's Creative Commons licence and your intended use is not permitted by statutory regulation or exceeds the permitted use, you will need to obtain permission directly from the copyright holder. To view a copy of this licence, visit http://creativecommons.org/licenses/by/4.0/ The Creative Commons Public Domain Dedication waiver (http://creativecommons.org/publicdomain/zero/1.0/) applies to the data made available in this article, unless otherwise stated in a credit line to the data. 


\section{Background}

Members of the ciliate class Heterotrichea Stein, 1859 are found in a wide range of aquatic biotopes. The heterotrichs are characterized by their typically large body size, somatic kineties composed of dikinetids with postciliodesmata and a prominent oral apparatus composed of a paroral membrane and an adoral zone of membranelles [1,2]. According to the two latest works on the classification of heterotrichs [3, 4], the class Heterotrichea contains ten families and about 58 genera, several of which are well-known, e.g., Condylostoma Bory de St. Vincent, 1824, Spirostomum Ehrenberg, 1834, and Stentor Oken, 1815. Gruberia Kahl, 1932 is rarely reported and has only three valid species: G. binucleata Dragesco, 1960, G. lanceolata (Gruber, 1884) Kahl, 1932, and G. uninucleata Kahl, 1932 [5, 6]. Of these, only G. lanceolata has been investigated using modern methods while its congeners remain insufficiently described $[5,6]$.

The genus Linostomella Aescht in Foissner et al., 1999 is monotypic and classified within the family Condylostomatidae Kahl in Doflein and Reichenow, 1929. The type species, L. vorticella, was first reported by Ehrenberg [7] as Bursaria vorticella due to the similarity of its body shape with the colpodid B. truncatella. Dujardin [8] doubted Ehrenberg's classification and transferred this species to the heterotrich genus Condylostoma because of it is holotrichous somatic ciliation and the conspicuous, spiraled adoral zone of membranelles. More than a century later, Jankowski [9] established the genus Linostoma for this species because it has no frontal cirrus/cirri, which is a diagnostic characteristics of Condylostoma. Subsequently, Aescht [10] recognized that Linostoma is a homonym and re-named it Linostomella. Recently, Rossi et al. [11] reported the molecular phylogenetic position of this genus.

In the present study, two heterotrich species, namely Gruberia foissneri spec. nov. and Linostomella vorticella, were isolated in Qingdao, China (Fig. 1), giving the opportunity to investigate their taxonomy and phylogeny based on both morphological and molecular data.

\section{Results}

Zoobank registration.

urn:lsid:zoobank.org:pub:6D18CFB8-D987-4825-9BA672A748AF29B4.

Family Gruberiidae Shazib et al., 2014.

Genus Gruberia Kahl, 1932.

Gruberia foissneri spec. nov. (Figs. 2, 3, 4, Table 1).

\section{Diagnosis}

Body about $400-800 \times 30-50 \mu \mathrm{m}$ in vivo, slightly contractile, slender with a conspicuously pointed caudal region; macronucleus sausage-shaped; pellicle with rod-shaped, dark-brownish cortical granules and rod-shaped mitochondria (?); 25-37 somatic kineties, several of which are shortened forming a suture near posterior end of body; 76-174 adoral membranelles; paroral membrane fragmented, comprising 29-75 pieces; marine habitat.

\section{Type locality}

A seawater aquarium in the Laboratory of Protozoology (N3603'45", E120¹9'52"), Qingdao, China. The seawater,

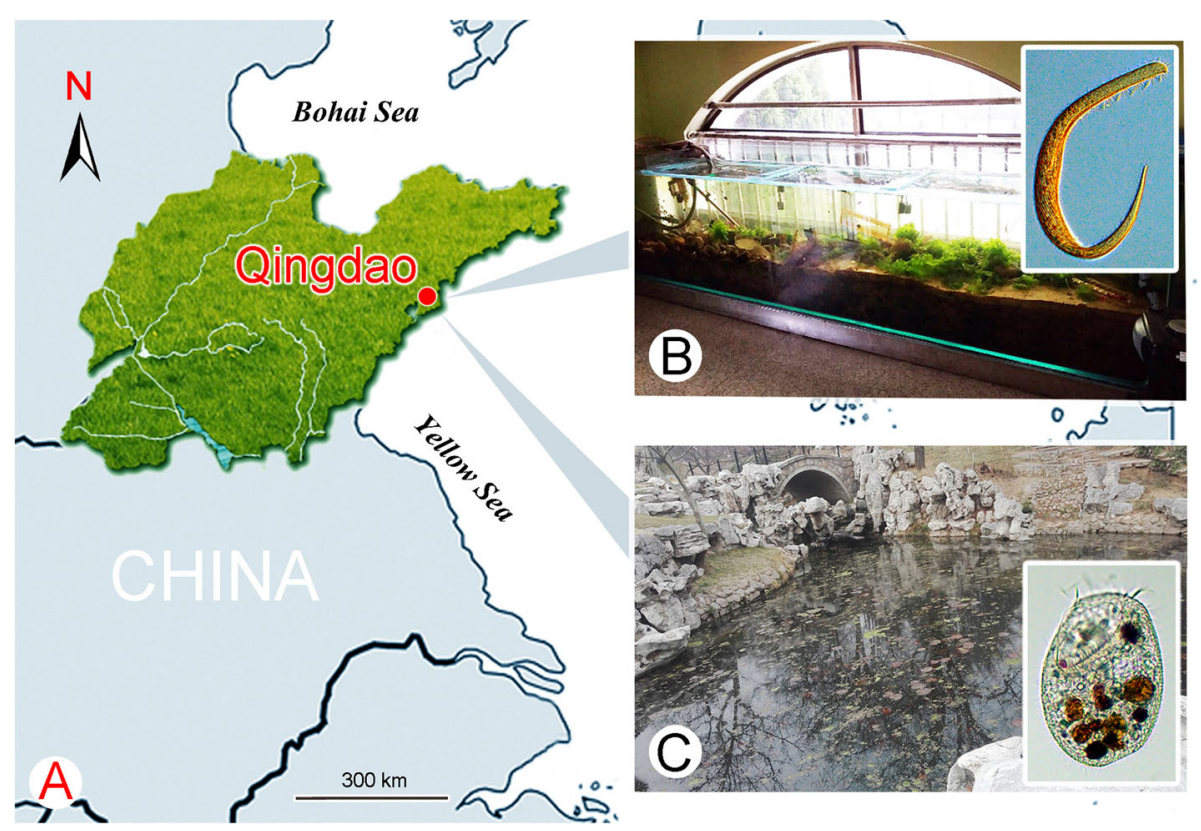

Fig. 1 Geographical location of Qingdao and photographs of the sampling sites. a, Portion of the map of China, showing location of Qingdao. b, The seawater aquarium from which Gruberia foissneri spec. nov. was isolated. c, The freshwater pond from which Linostomella vorticella was isolated 


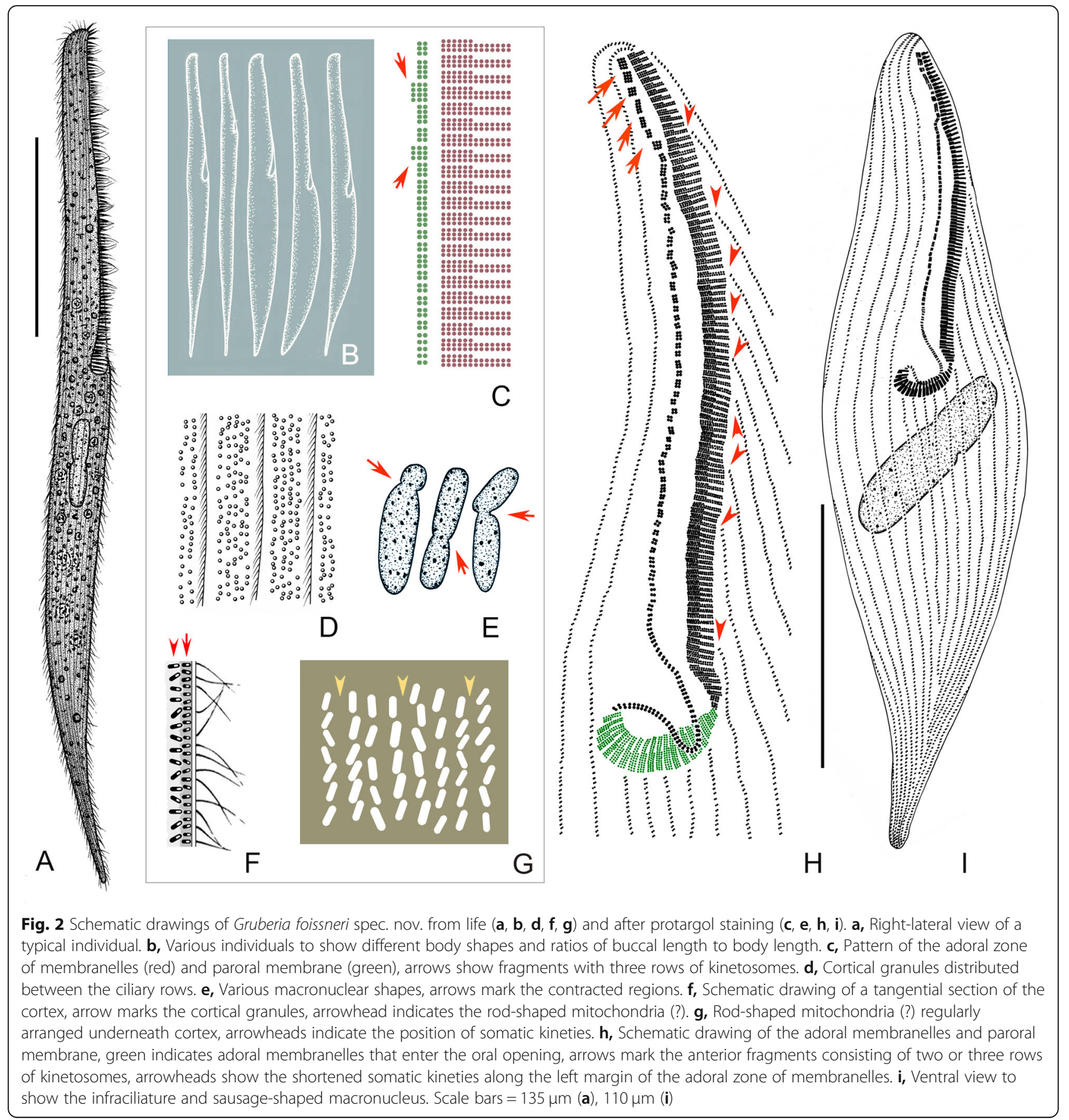

stones and sand in the aquarium were collected from Taipingjiao Marine Wetland Park and the Second Beach in Qingdao along with living sea anemones and Ulva lactuca. The water temperature was $24^{\circ} \mathrm{C}$ and salinity was $30 \mathrm{ppt}$.

\section{Type deposition}

One protargol-stained slide containing the holotype specimen marked with an ink circle and one slide with paratype specimens are deposited in the Laboratory of Protozoology, Ocean University of China, China, with registration numbers CY201812200101 and CY201812200102. The other two paratype slides are deposited in the Natural History Museum, London, UK, with registration numbers NHMUN 2020.4.6.1 and NHMUN 2020.4.6.2.

\section{Dedication}

We dedicate this new species to Prof. Wilhelm Foissner, Salzburg University, Austria, in recognition of his tremendous contributions to the study of ciliates. 


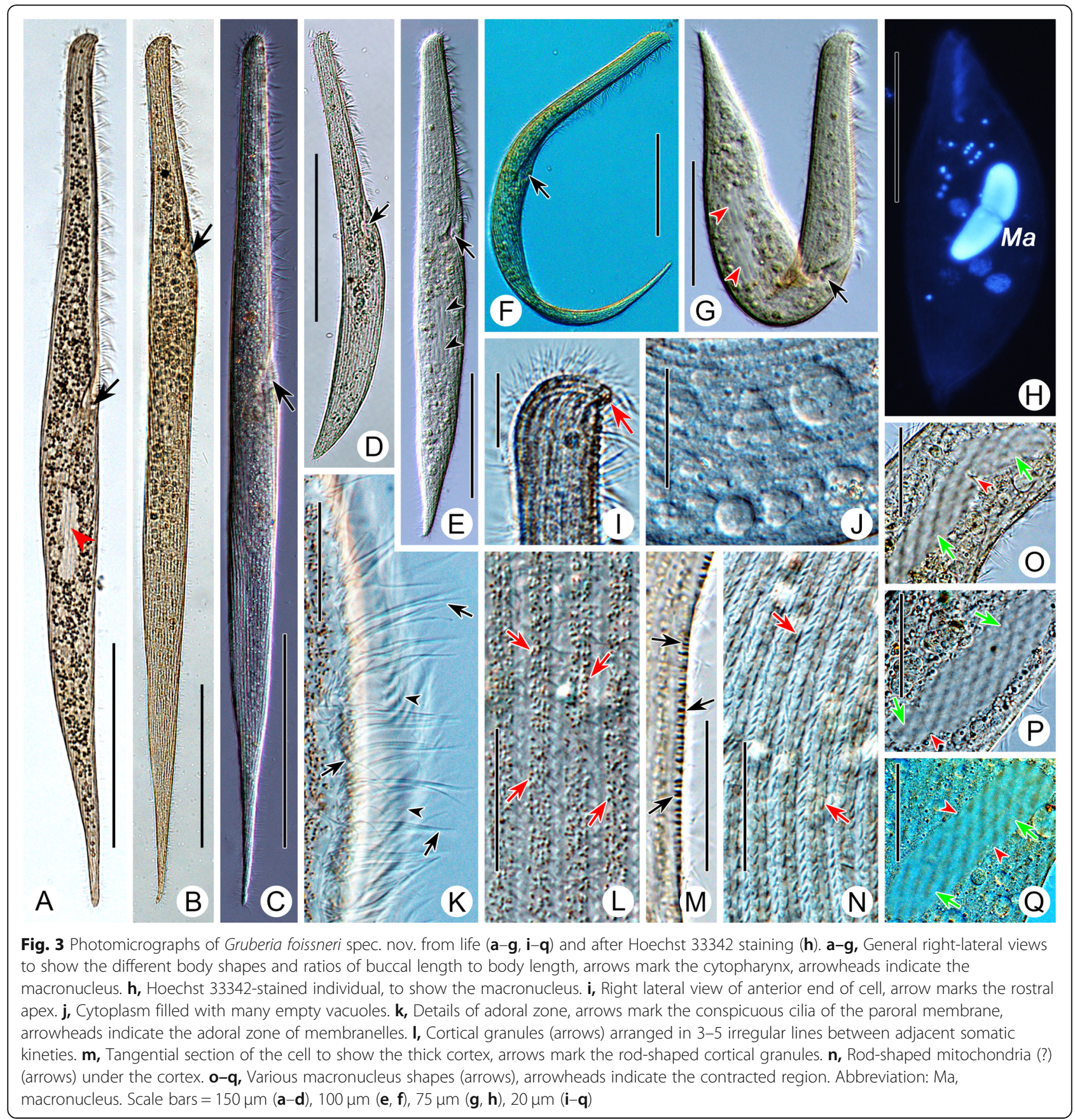

\section{Gene sequence}

The SSU rDNA sequence derived from a single cell isolated from the same population as the holotype is deposited in GenBank (accession number MN783327).

\section{Description}

When fully extended, cell about $400-800 \times 30-50 \mu \mathrm{m}$ in vivo, on average about $560 \times 40 \mu \mathrm{m}(185-430 \times 57-$ $145 \mu \mathrm{m}$ in protargol-stained specimens) with length to width ratio about 10-18:1. Body flexible and slightly contractile, elliptical in cross-section, anterior end beak- like, posterior part gradually narrows to a pointed end (Fig. 2a, Fig. 3a-e, i). Macronucleus sausage-shaped with an obvious depression (Fig. 2e, Fig. 3o-q, Fig. 4h). Micronucleus difficult to recognize either in vivo or in protargol preparations. Contractile vacuole absent. Pellicle thick with rod-shaped, dark-brownish cortical granules (about $1.2 \times 0.5 \mu \mathrm{m}$ in size) embedded in cortex, forming 3-5 irregular lines between adjacent somatic kineties (Fig. 2d, f, Fig. 3l, m). Mitochondria (?) rod-shaped, about $2.0 \times 0.7 \mu \mathrm{m}$ in size, located underneath cortex forming three or four rows between adjacent ciliary rows 


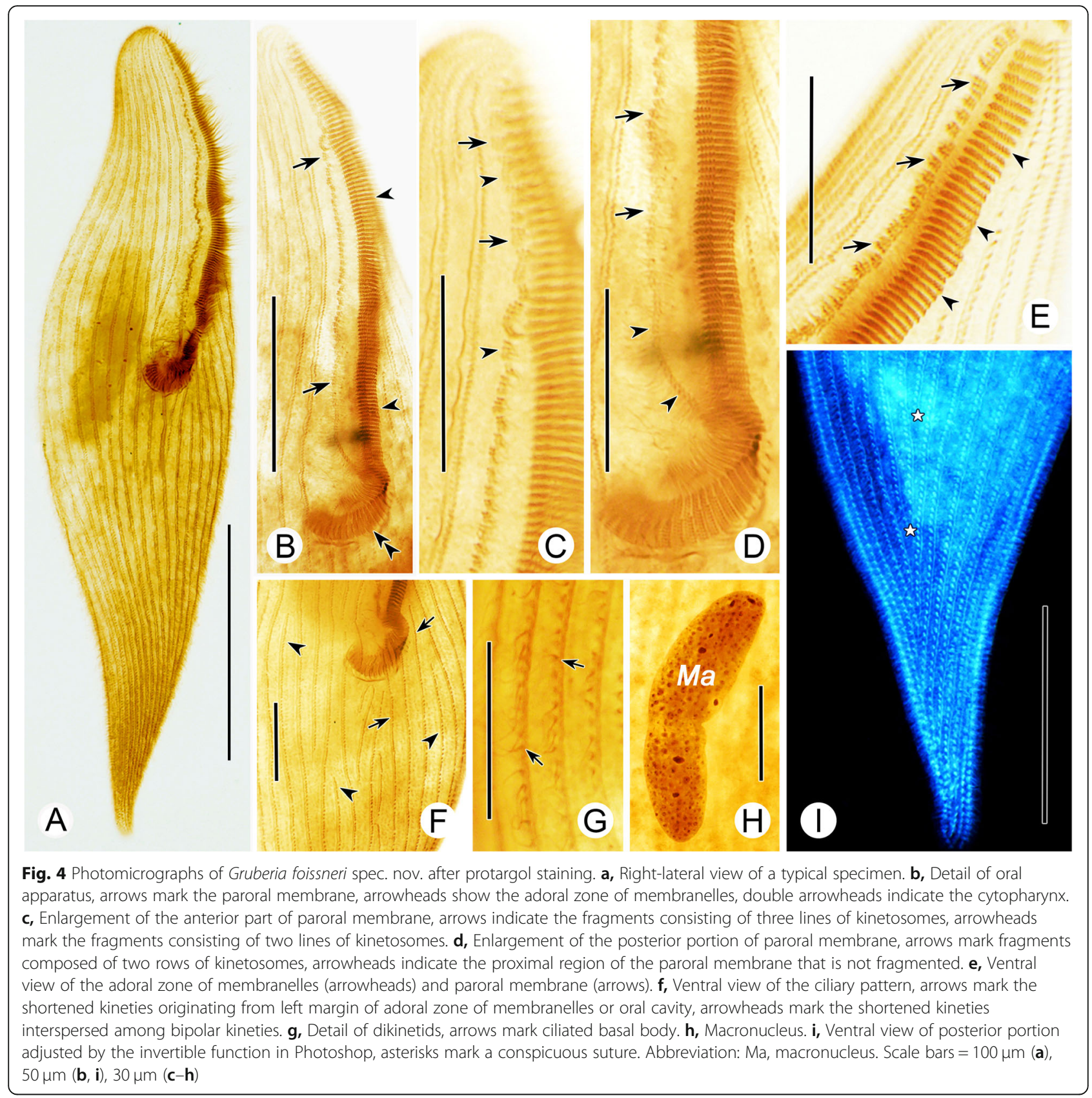

(Fig. 2f, g, Fig. 3n). Cytoplasm opaque at low magnification due to numerous small granules and food vacuoles (Fig. 3a-g, j). Locomotion by gliding over substratum.

Twenty-five to 37 somatic kineties composed of dikinetids, only one basal body of each dikinetid bears a cilium (Fig. 2h, i, Fig. 4g). Somatic cilia 5-7 $\mu \mathrm{m}$ long. About 9-21 shortened somatic kineties, most of which originate from left margin of adoral zone of membranelles or oral cavity, remaining ones interspersed among bipolar kineties (Fig. 2h, Fig. 4f). Several shortened kineties form a conspicuous suture on ventral side near posterior end of body (Fig. 2i, Fig. 4i).
Length of oral area relative to body length highly variable, ranging from 25 to $45 \%$ (Fig. 2b, Fig. 3a-e). Adoral zone extends from apical end to main body, oral groove slightly curved to right side, twisted in proximal region making a half-turn as it enters the buccal cavity (Fig. 2h, i, Fig. 3a-g, Fig. 4b, d). About 76-174 adoral membranelles, each composed of one short and two long rows of basal bodies (Fig. 2c, h, Fig. 4b, d). Cilia of membranelles 11$16 \mu \mathrm{m}$ long in vivo. Paroral membrane fragmented into about 29-75 pieces and arranged along right side of adoral zone of membranelles, almost all fragments composed of two rows of kinetosomes except several anterior ones 
Table 1 Morphometric data for Gruberia foissneri spec. nov. (G. foi) and Linostomella vorticella (L. vor)

\begin{tabular}{|c|c|c|c|c|c|c|c|c|}
\hline Character & Species & Min & Max & Mean & M & SD & $\mathrm{CV}$ & $n$ \\
\hline \multirow[t]{2}{*}{ Body, length in vivo $(\mu \mathrm{m})$} & G. foi & 400 & 800 & 560.0 & 525.0 & 144.8 & 25.9 & 7 \\
\hline & L. vor & 135 & 205 & 175.0 & 175.0 & 22.2 & 12.7 & 11 \\
\hline \multirow[t]{2}{*}{ Body, width in vivo $(\mu \mathrm{m})$} & G. foi & 30 & 50 & 39.3 & 35.0 & 6.8 & 17.2 & 7 \\
\hline & L. vor & 70 & 110 & 93.2 & 95.0 & 11.3 & 12.2 & 11 \\
\hline \multirow[t]{2}{*}{ Body, length ${ }^{a}(\mu \mathrm{m})$} & G. foi & 185 & 430 & 325.1 & 334.0 & 53.9 & 16.6 & 31 \\
\hline & L. vor & 150 & 269 & 205.4 & 203.0 & 27.5 & 13.4 & 39 \\
\hline \multirow[t]{2}{*}{ Body, width ${ }^{a}(\mu m)$} & G. foi & 57 & 145 & 87.1 & 86.0 & 15.8 & 18.1 & 31 \\
\hline & L. vor & 111 & 204 & 154.7 & 156.0 & 21.7 & 14.1 & 39 \\
\hline \multirow[t]{2}{*}{ Oral area, length in vivo $(\mu \mathrm{m})$} & G. foi & 145 & 295 & 200.7 & 195.0 & 46.2 & 23.0 & 7 \\
\hline & L. vor & 55 & 110 & 80.0 & 85.0 & 16.5 & 20.6 & 11 \\
\hline \multirow[t]{2}{*}{ Oral area, length ${ }^{a}(\mu m)$} & G. foi & 72 & 190 & 135.7 & 140.5 & 27.4 & 20.2 & 30 \\
\hline & L. vor & 68 & 130 & 96.9 & 96.5 & 16.2 & 16.7 & 34 \\
\hline \multirow[t]{2}{*}{ Adoral membranelles, number } & G. foi & 76 & 174 & 136.7 & 141.0 & 25.8 & 18.8 & 26 \\
\hline & L. vor & 36 & 51 & 43.5 & 44.0 & 3.7 & 8.5 & 34 \\
\hline \multirow[t]{2}{*}{ Somatic kineties, number (including bipolar and shortened somatic kineties) } & G. foi & 25 & 37 & 32.4 & 32.5 & 3.2 & 9.9 & 28 \\
\hline & L. vor & 37 & 51 & 42.4 & 42.5 & 3.5 & 8.2 & 22 \\
\hline \multirow[t]{2}{*}{ Shortened somatic kineties, number } & G. foi & 9 & 21 & 14.4 & 14.5 & 3.3 & 23.2 & 26 \\
\hline & L. vor & 11 & 18 & 13.5 & 13.0 & 2.0 & 14.7 & 25 \\
\hline \multirow[t]{2}{*}{ Fragments of paroral membrane, number } & G. foi & 29 & 75 & 56.7 & 55.5 & 10.9 & 19.3 & 24 \\
\hline & L. vor & - & - & - & - & - & - & - \\
\hline \multirow[t]{2}{*}{ Ma nodules, number } & G. foi & 1 & 1 & 1.0 & 1.0 & 0 & 0 & 21 \\
\hline & L. vor & 5 & 12 & 9.0 & 10.0 & 1.8 & 20.4 & 31 \\
\hline \multirow[t]{2}{*}{ Ma, length $(\mu \mathrm{m})$} & G. foi & 68 & 100 & 85.0 & 84.0 & 10.4 & 12.2 & 21 \\
\hline & L. vor ${ }^{b}$ & 12 & 41 & 26.8 & 26.0 & 7.9 & 29.5 & 31 \\
\hline \multirow[t]{2}{*}{ Ma, width $(\mu \mathrm{m})$} & G. foi & 19 & 33 & 24.8 & 25.0 & 3.7 & 15.0 & 21 \\
\hline & L. vor ${ }^{b}$ & 9 & 26 & 17.1 & 17.0 & 3.0 & 17.7 & 31 \\
\hline
\end{tabular}

Abbreviations: CV Coefficient of variation in \%; M Median; Ma Macronucleus; Max Maximum; Mean Arithmetic mean; Min Minimum; $n$ Number of specimens; SD standard deviation

${ }^{\mathrm{a}}$ Data based on protargol-stained specimens, ${ }^{\mathrm{b}}$ Macronuclear nodules were selected randomly in each individual, - Data not available

which comprise three rows; paroral membrane conspicuous, comprising two portions: fragmented main portion with each fragment composed of $2-5$ pairs of kinetosomes; twisted, unfragmented posterior portion (Fig. 2c, h, i, Fig. 4b-e). Cilia of paroral membrane conspicuous, welldeveloped, $19-22 \mu \mathrm{m}$ long in vivo (Fig. 3k).

Family Condylostomatidae Kahl in Doflein \& Reichenow, 1929.

Genus Linostomella Aescht in Foissner et al., 1999. Linostomella vorticella (Ehrenberg, 1833) Aescht in Foissner et al., 1999 (Figs. 5, 6, 7, Table 1).

\section{Synonyms.}

1833 Bursaria vorticella n. sp. - Ehrenberg, Abh dt Akad Wiss 237 (original description without illustration) (present work: Table 3) [7].

1838 Bursaria vorticella Ehrenberg, 1833 - Ehrenberg, Infusionsthierchen 326, 327 [Fig. VI] (brief redescription) [24].
1841 Bursaria vorticella Ehrenberg - Dujardin, Zoophytes 511 (without morphological description, only simple review of Ehrenberg's works) [8].

1870 Condylostoma stagnale - Wrześniowski, Z wiss Zool 20: 487-489 [Fig. 20] (redescription of living morphology) (present work: Table 3) [12].

1922 Condylostoma vorticella (Ehrenberg) Dujardin Penard, Études Infusoires 201, 202 [Fig. 200] (morphological redescription based on living cell) (present work: Table 3) [13].

1924 Condylostoma vorticella (Ehrenberg, 1833) Fauré-Fremiet, Bull biol Fr Belg 6: 136-139 [Fig. 45] (redescription from life) (present work: Table 3) [14].

1932 Condylostoma (Bursaria) vorticella (Ehrenberg, 1833) - Kahl, Tierwelt Dtl 25: 457 [Figs. 1214 on page 454, Fig. 28 on page 458] (short revision with simple redescription) (present work: Table 3) [15]. 


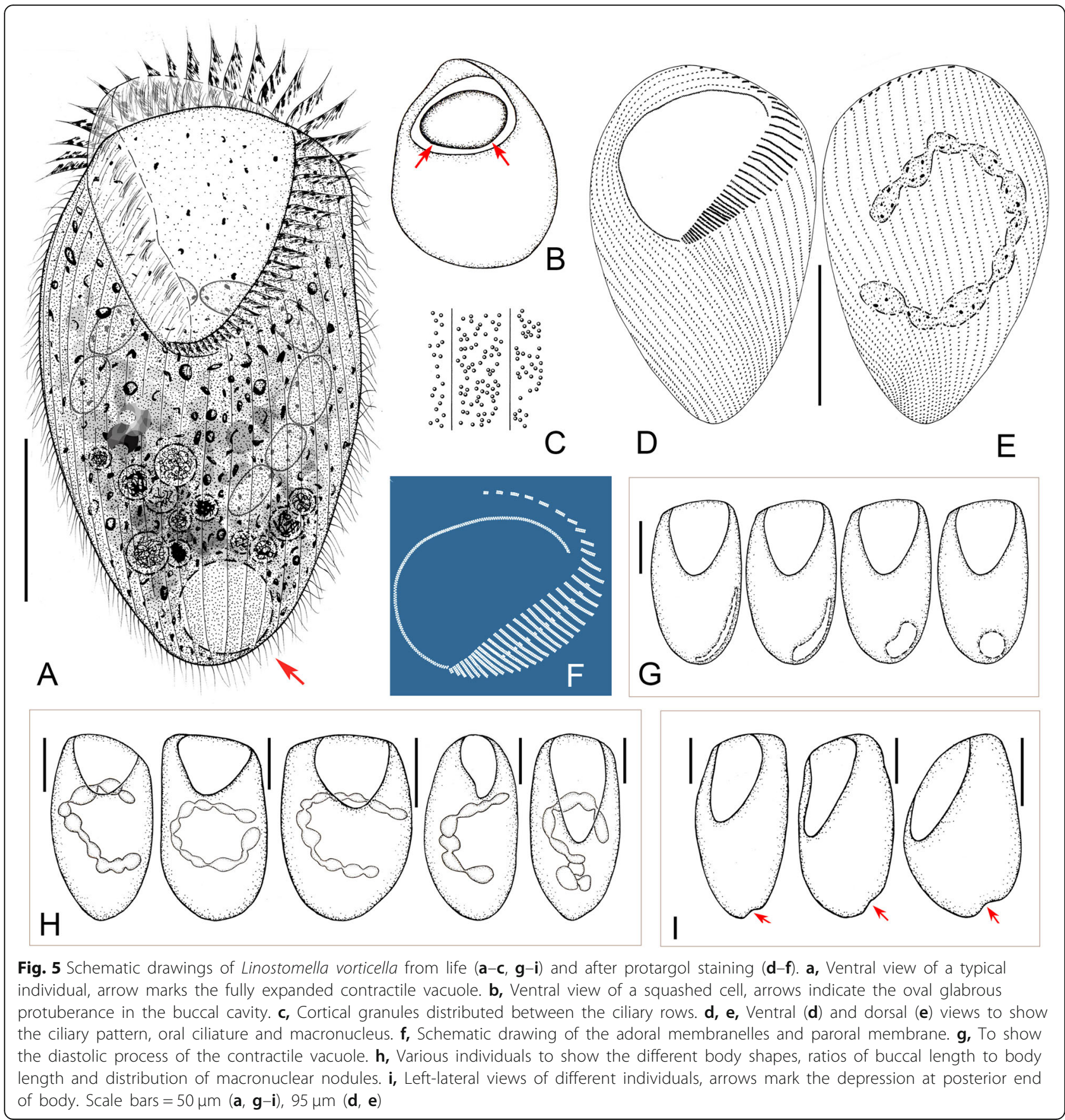

1933 Condylostoma vorticella (Ehrenberg) Dujardin 1841 - Wang \& Nie, Contr biol Lab Sci Soc China 10: 45-48 [Fig. 36] (redescription of morphology based on living cells) (present work: Table 3) [16].

1967 Condylostoma vorticella - Tuffrau, Protistologica 3: 381, 382 [Fig. 7] (brief redescription) [25].

1974 Condylostoma vorticella (Ehrenberg) - Pätsch, Arb Inst landw Zool Bienenkd 1: 48, 49 [Fig. 38] (brief redescription, including the infraciliature information) (present work: Table 3) [19].
1978 Linostoma vorticella Ehrenberg - Jankowski, Tezisy Dokl zool Inst Akad Nauk SSSR, Jahr 39 (proposal for the establishment of genus Linostoma) [9].

1986 Condylostoma vorticella Ehrenberg, 1833 - Dragesco \& Dragesco-Kernéis, Faune Tropicale 391-393 [Figs. A-D] (simple redescription including infraciliature information) (present work: Table 3) [20].

1991 Condylostoma vorticella (Ehrenberg, 1838) Packroff \& Wilbert, Arch Protistenkd 140: 132-134 [Fig. 7] (detailed morphological redescription from life 


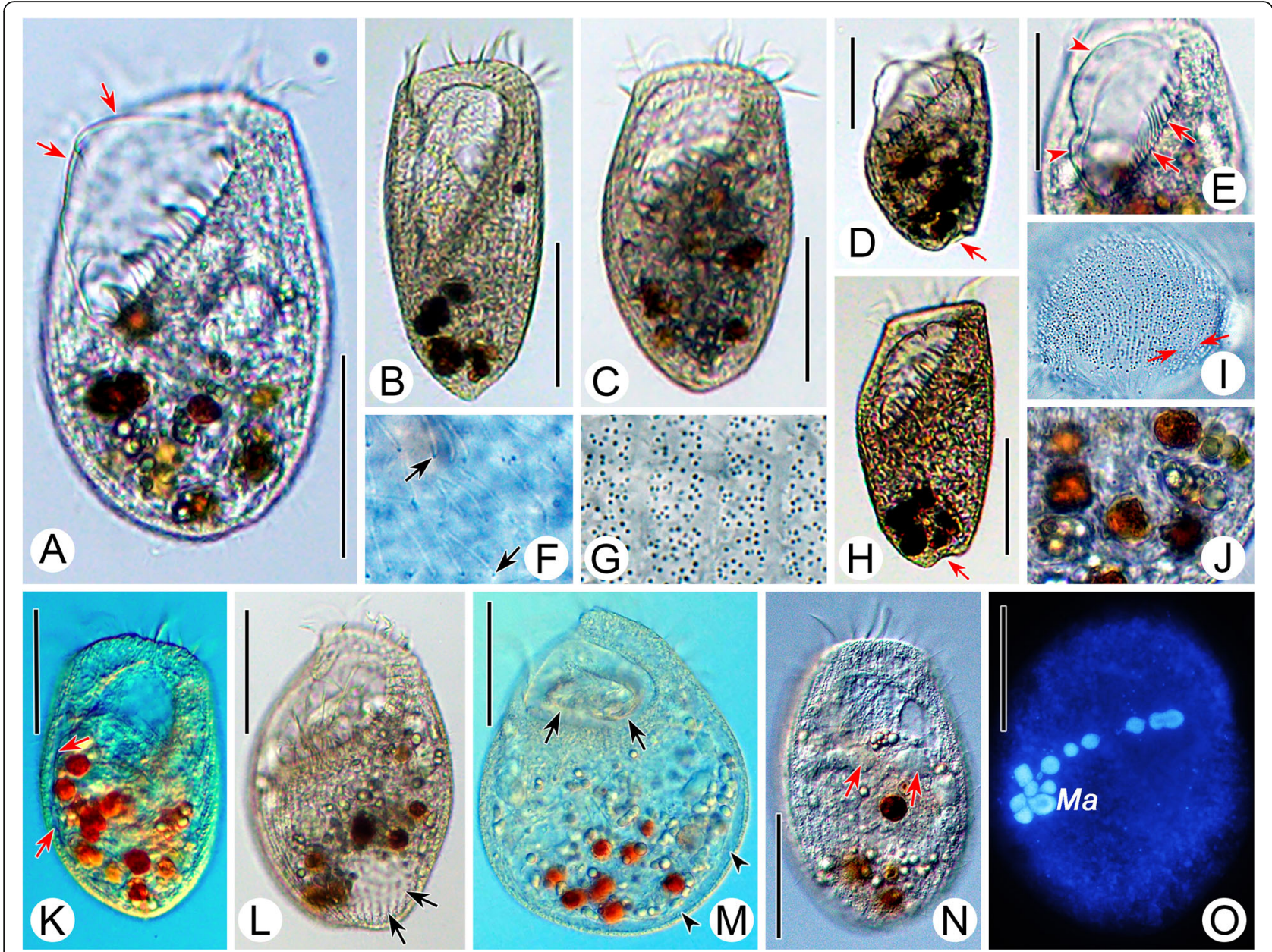

Fig. 6 Photomicrographs of Linostomella vorticella from life (a-n) and after Hoechst 33342 staining (o). a-c, Various individuals to show the different body shapes and ratios of buccal length to body length, arrows mark the prominent paroral membrane. $\mathbf{d}$, $\mathbf{h}$, Left-lateral views of different cells, arrows mark the depression at posterior end of body. e, Detail of oral area, arrows mark the adoral zone of membranelles, arrowheads show the paroral membrane. $\mathbf{f}$, Detail of cilia, arrows denote each basal body bears a cilium. $\mathbf{g}$, Tiny cortical granules densely distributed between ciliary rows. i, Detail of the glabrous protuberance in oral cavity, arrowheads mark the fiber-like stripes. j, Food vacuoles with algae. $\mathbf{k}$, Dorsal view of an individual full of food vacuoles, arrows mark the collecting canal. I, Contractile vacuole (arrows) near posterior end of body. $\mathbf{m}$, Ventral view of a squashed cell, arrows indicate the glabrous protuberance, arrowheads mark different stages in the diastolic process of the contractile vacuole. $\mathbf{N}$, Dorsal view of a cell, arrows mark the moniliform macronucleus. $\mathbf{0}$, Hoechst 33342-stained individual to show the moniliform macronucleus. Abbreviation: Ma, macronucleus. Scale bars $=60 \mu \mathrm{m}(\mathbf{a}, \mathbf{d}, \mathbf{e}, \mathbf{k}, \mathbf{m}, \mathbf{n}), 90 \mu \mathrm{m}(\mathbf{b}, \mathbf{h}), 75 \mu \mathrm{m}(\mathbf{c}, \mathbf{l}, \mathbf{o})$

and protargol-stained individuals) (present work: Table 3) [21].

1992 Linostoma vorticella (Ehrenberg, 1833) Jankowski, 1978 - Foissner et al., Informationsberichte des Bayer Landesamtes für Wasserwirtschaft 5/92: 390-393 [Figs. 1-14] (diagnosis based on previous reports) (present work: Table 3) [26].

1999 Linostomella vorticella (Ehrenberg, 1833) Aescht nov. nom. nov. comb. - Foissner et al., Informationsberichte des Bayerischen Landesamtes für Wasserwirtschaft 3/99: 655-661 [Figs. 1-32] (improved diagnosis provided based on detailed morphological redescription) (present work: Table 3) [22].

2007 Linostomella vorticella (Ehrenberg, 1838) Alekperov et al., Protistology 5: 117, 118 [Fig. 9,
Plate 2D on page 114] (simple redescription) (Present work: Table 3) [23].

Prior to the current investigation, Linostomella vorticella has been found and reported numerous times, but some details of its morphology remain unknown. Based on both previous and present studies, an improved diagnosis is supplied.

\section{Improved diagnosis}

Cell size in vivo about $90-210 \times 70-160 \mu \mathrm{m}$; body ovoidal or ellipsoidal with anterior end obliquely truncated; macronucleus moniliform with 2-15 nodules; single contractile vacuole posteriorly positioned with a long collecting canal; cortical granules colorless to dark-gray; 


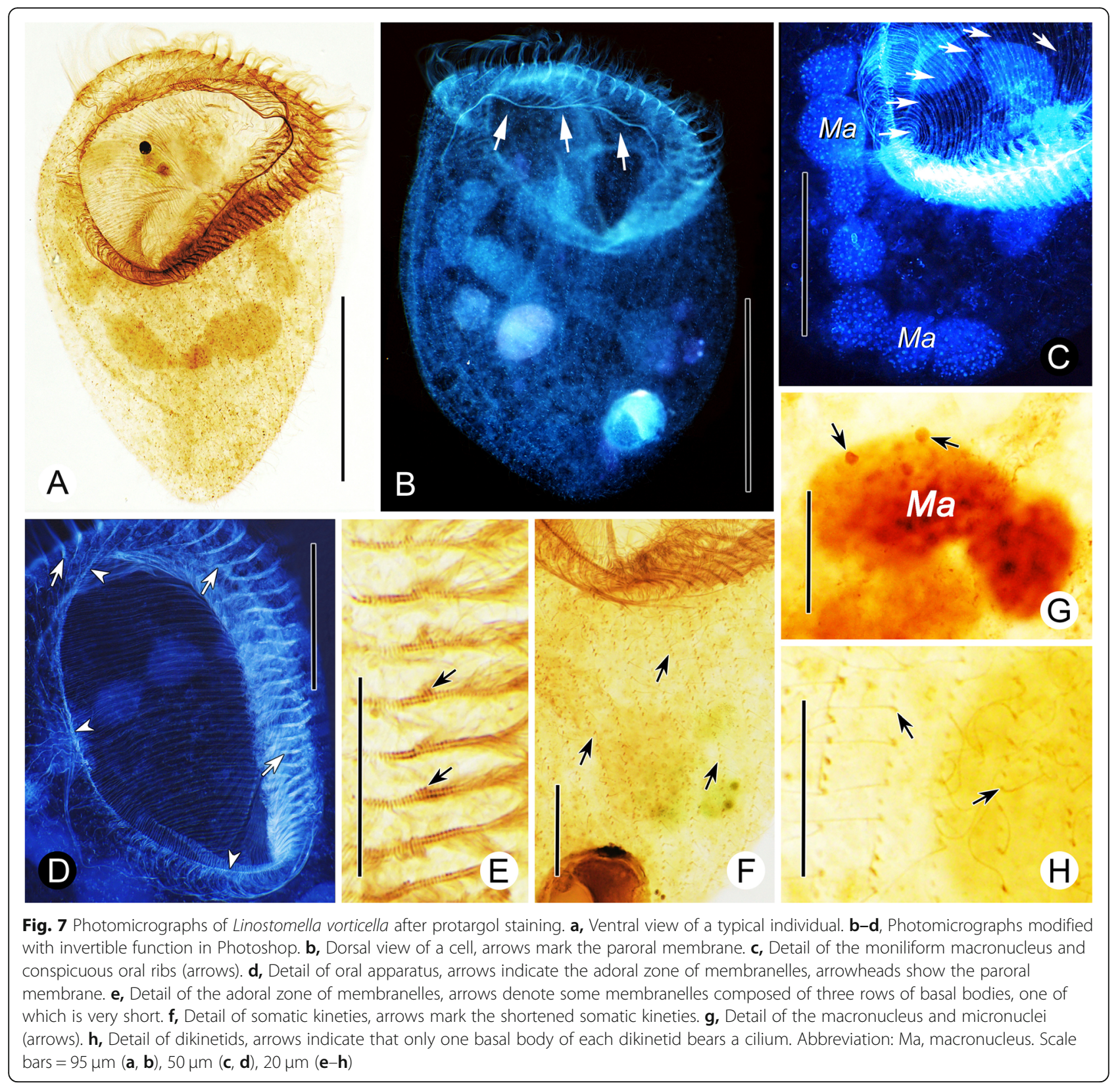

about 26-51 somatic kineties; buccal cavity conspicuous with numerous oral ribs; 36-51 adoral membranelles; freshwater and marine habitats.

\section{Voucher slides}

Three voucher slides with protargol-stained specimens are deposited in the Laboratory of Protozoology, Ocean University of China (OUC) with registration numbers: CY2019010501-01, 02, 03.

\section{Morphological description of the Qingdao population}

Cell size $135-205 \times 70-110 \mu \mathrm{m}$ in vivo, about $175 \times$ $95 \mu \mathrm{m}$ on average. Body ovoid in outline with length to width ratio about 1.5-2.0:1 (Fig. 5a, h, Fig. 6a-c). In general, anterior half wider than posterior half, apical end obliquely truncated, posterior end with a slight depression (Fig. 5h, i, Fig. 6d, h). Macronucleus moniliform with 5-12 nodules, located in middle portion of body (Fig. 5a, e, h, Fig. 6n, o, Fig. 7a, c). Micronuclei inconspicuous, closely associated with macronuclear nodules (Fig. $7 \mathrm{~g}$ ). Contractile vacuole in posterior region, varies in shape during diastolic process, with a collecting canal that extends to anterior region of body (Fig. 5a, g, Fig. 6k$\mathrm{m})$. Pellicle soft and thin with numerous spherical, darkgray cortical granules (about $0.9 \mu \mathrm{m}$ in diameter) densely distributed between ciliary rows (Fig. 5c, Fig. 6g). 
Cytoplasm colorless, invariably filled with numerous globular particles and food vacuoles filled with algae (Fig. 5a, Fig. 6 j, $k-n$ ). Locomotion by swimming while rotating about main body axis.

Thirty-seven to 51 somatic kineties composed of dikinetids, only one basal body of each dikinetid bears a cilium (Fig. 5d, e, Fig. 6f, Fig. 7h). Somatic cilia 9-12 $\mu \mathrm{m}$ long. About 11-18 ventral kineties are shortened since they originate below buccal cavity; all dorsal kineties extend along complete length of cell (Fig. 5d, e, Fig. 7a, b, f).

Buccal cavity prominent, length about $35-60 \%$ of body length, with numerous oral ribs (Fig. 5h, Fig. 6a-c, Fig. 7c, d). Oval glabrous protuberance with fiber-like stripes visible in slightly squashed specimens (Fig. 5b, Fig. 6i, m). Adoral zone of membranelles prominent, composed of 36-51 membranelles, most of which consist of two rows of basal bodies of equal length; several adoral membranelles in middle portion consist of three rows of basal bodies, third row with only two or three basal bodies (Fig. 5d, f, Fig. 7e). Cilia of adoral membranelles $20-30 \mu \mathrm{m}$ long in vivo. Paroral membrane conspicuous, curved and lies along right margin of buccal cavity, anterior portion curves toward the left side of buccal cavity, posterior portion located near distal end of adoral zone (Fig. 6a, e, Fig. 7b-d).

\section{Molecular data and phylogenetic analyses}

The two new SSU rDNA sequences obtained in this study were deposited in the GenBank database with lengths, $\mathrm{G}+\mathrm{C}$ contents, and accession numbers as follows: Gruberia foissneri spec. nov., $1627 \mathrm{bp}, 46.22 \%$, MN783327; Linostomella vorticella, $1683 \mathrm{bp}, 46.88 \%$, MN783328. The Maximum likelihood (ML) and Bayesian inference (BI) trees based on SSU rDNA data had nearly identical topologies, therefore only the ML tree is shown with support values from both analyses (Fig. 8).

Seven sequences of Gruberia were included in the present analyses, i.e., the newly obtained sequence of $G$. foissneri spec. nov. and six sequences obtained from the GenBank database. These seven sequences form a maximally supported clade (100\% ML, $1.00 \mathrm{BI})$ that represents the family Gruberiidae in the SSU rDNA tree (Fig. 8).

Linostomella vorticella and two other Linostomella sequences (LN869952, LN870136) cluster together with maximal support (100\% ML, $1.00 \mathrm{BI}$ ), forming a sistergroup to the Condylostomides assemblage (100\% ML, $1.00 \mathrm{BI}$ ). The Linostomella-Condylostomides clade comprises one of the two sub-clades of the family Condylostomatidae; the other sub-clade contains the genera Condylostoma, Chattonidium, and Condylostentor.

\section{Discussion}

\section{Comments on Gruberia foissneri spec. nov.}

The genus Gruberia was established by Kahl [15] with G. uninucleata as the type species. The morphology of
Gruberia is similar to that of Spirostomum in having an elongated, slightly contractile body and a well-developed peristomial region, although the body of Gruberia lacks spiraling or torsion $[6,27]$. Seven nominal species of Gruberia have been reported: G. aculeata Ozaki \& Yagiu, 1941, G. beninensis Dragesco \& DragescoKernéis, 1986, G. binucleata Dragesco, 1960, G. calkinsi Beltran, 1933, G. lanceolata (Gruber, 1884) Kahl, 1932, G. nematodomorpha Lepsi, 1965, and G. uninucleata Kahl, 1932 [15, 20, 28-32]. In their generic review, Campello-Nunes et al. [5] and Chen et al. [6] synonymized G. aculeata, G. beninensis and G. calkinsi with G. lanceolata, and considered G. nematodomorpha as a nomen nudum. We accept these decisions and recognize only four valid species, namely G. uninucleata, G. binucleata, G. lanceolata and G. foissneri spec. nov.

Gruberia foissneri spec. nov. can be easily distinguished from two of its three congeners by its sausageshaped macronucleus (vs. two oval macronuclei in $G$. binucleata and a moniliform macronucleus in G. lanceolata) (Table 2) $[5,6,29,30]$. In contrast, G. foissneri spec. nov. is very similar to $G$. uninucleata which was originally discovered by Kahl [15] from an aquarium in Helgoland, Germany. Kahl [15] described the organism based on living observations as follows: "Gr. 300-650 $\mu$; Schlank spindelförmig, im hinteren Drittel gleichmäßig $\mathrm{zu}$ einem dünnen Schwanzstachel ausgezogen, der mit kurzkonischer Spitze endigt; 8-10 Reihen auf einer Seite; Ma, ellipsoid" (translation: size 300-650 $\mu \mathrm{m}$; slender spindle-shaped, posterior third evenly narrowed to a thin tail ending with short conical tip; 8-10 ciliary rows on one side; macronucleus, ellipsoid) (Table 2). Dragesco [33] supplied comprehensive data of a Roscoff population based on living morphology and infraciliature (Table 2). According to these two reports, G. uninucleata can be characterized by: (1) cell size about 250$650 \mu \mathrm{m}$ in vivo; (2) slender body shape with a pointed caudal region; (3) single ellipsoidal macronucleus; (4) about 20 somatic kineties; (5) oral area about $25-33 \%$ of body length, with 40-82 adoral membranelles about 70 on average; (6) paroral membrane fragmented, comprising about 23-29 pieces (Table 2). Gruberia foissneri spec. nov. is very similar to G. uninucleata in the living morphology, however the former can be easily distinguished from the latter by the following characters: (1) number of somatic kineties (25-37, about 32 on average vs. about 20 in G. uninucleata); (2) number of adoral zone of membranelles (76-174, about 137 on average vs. $40-82$, about 70 on average in G. uninucleata); (3) number of paroral membrane fragments (29-75, about 57 on average vs. $23-29$ in G. uninucleata); (4) macronucleus shape (sausageshaped with an obvious depression vs. ellipsoidal in G. uninucleata). 


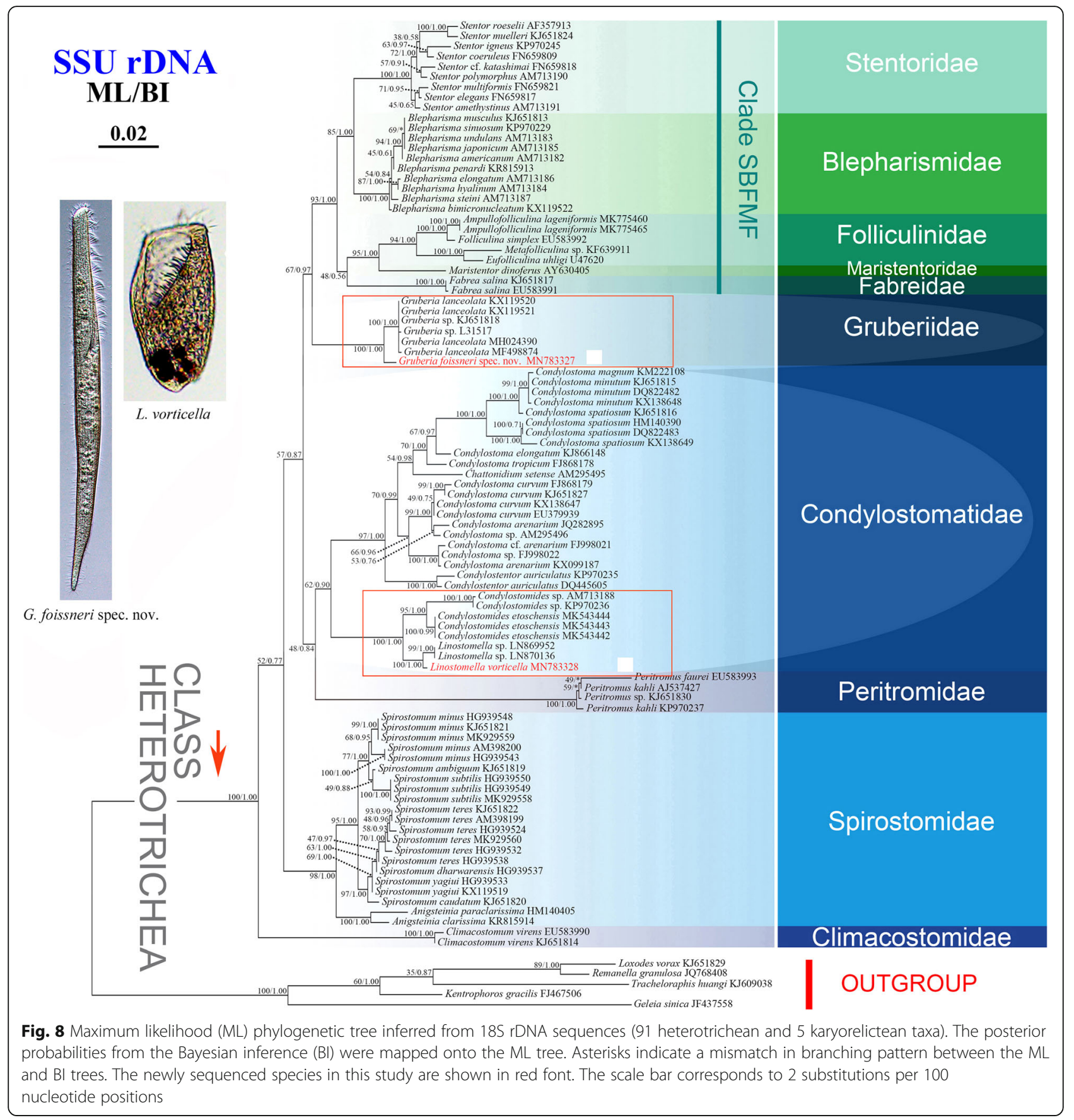

It is worth noting that Dragesco [34] described a smaller Gruberia uninucleata $(200 \mu \mathrm{m}$ on average) based on living observations of a Port-Etienne population. Like the population described by Kahl [15], this population has an ellispoidal macronucleus but possesses about 40 (vs. $8-10$ on one side in the population described by Kahl) somatic kineties. In view of the unavailability of key morphological characters and difference in the number of somatic kineties, we suspect that this population may either be conspecific with Gruberia foissneri spec. nov. or represent another species. Further studies are needed to test this hypothesis.

\section{Comments on Linostomella vorticella}

Linostomella vorticella, which is mainly found in freshwater, was originally reported as Bursaria vorticella by Ehrenberg [7]. It was subsequently named Condylostoma vorticella (Ehrenberg, 1833) Dujardin and then Linostoma vorticella (Ehrenberg, 1833) Jankowski [9, 13]. Aescht [10] reported that Linostoma Jankowski, 1978 is 


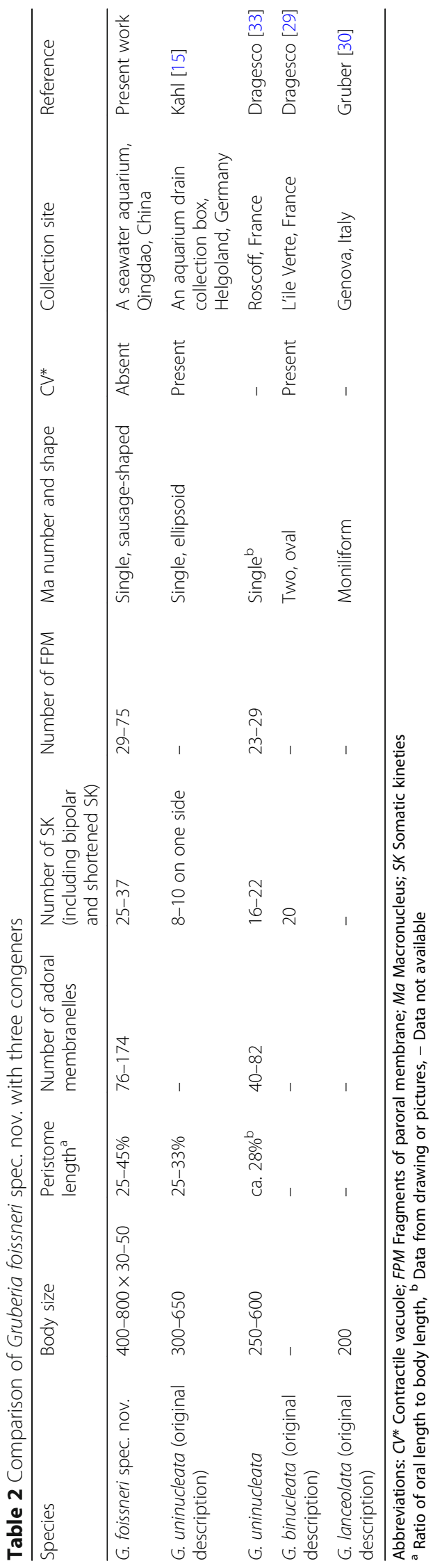


a homonym, thus she re-named it Linostomella. For nomenclatural purposes the genus and species names should be cited as Linostomella Aescht in Foissner et al., 1999 and Linostomella vorticella (Ehrenberg, 1833) Aescht in Foissner et al., 1999, respectively [22].

Linostomella vorticella resembles Condylostoma in having an expansive oral region at the anterior end of the body and a conspicuous paroral membrane, therefore it was for a long time classified in the genus Condylostoma. However, L. vorticella can be distinguished from Condylostoma by the presence of a contractile vacuole (absent in Condylostoma), lack of frontal cirri (present in Condylostoma) and only one kinetosome of each dikinetid bears a cilium (both kinetosomes ciliated in Condylostoma) [35-38].

Linostomella vorticella was originally reported by Ehrenberg [7] under the name Bursaria vorticella. Ehrenberg's description, however, was rather superficial which made the subsequent re-identification of this organism difficult. According to the original and subsequent investigations, this species should be recognizable by the following characters: (1) body shape spherical to ellipsoidal, posterior end rounded, anterior end always slightly truncated; (2) conspicuous oral cavity that occupies about half the body length; (3) macronucleus moniliform with nodules arranged in a horseshoe-shape or an oblique line; (4) contractile vacuole at the posterior end of the body with a long collecting canal (Table 3). Furthermore, three populations (two from Germany and one from Austria) were investigated using a combination of in vivo observations and histological staining methods and were found to closely resemble the original population [7, 19, 21]. The Qingdao population corresponds closely with the populations from Europe. We therefore believe that its identification as $L$. vorticella is correct.

Gelei [17] reported an organism that resembles $L$. vorticella in all key characters except the number of somatic kineties (60-70 vs. $26-51$ in L. vorticella) (Table 3). Although the description provided by Gelei [17] was brief, the somatic kinety number is an important character in ciliate species circumscription, so we posit that this population may represent a different species of Linostomella. Dragesco [18] described an isolate collected from a freshwater pond in Mokolo, Cameroon, which has fewer adoral membranelles (19-22) than L. vorticella (36-51) (Table 3). We agree with Foissner et al. [22] that this population either represents a different species or was mis-observed. Alekperov et al. [23] reported a marine population of $L$. vorticella from the Mexican Gulf, the key characters of which are consistent with the freshwater populations from Germany, Austria and Qingdao (Table 3). In general, habitat is an important character for ciliate species circumscription, so further evidence is needed to verify the identity of this marine population.
In addition to the populations discussed above, $L$. vorticella has been reported numerous times (Table 3) [12-16, 20]. However, we cannot make effective comparisons due to insufficient morphological descriptions in these reports.

\section{Phylogenetic analyses based on SSU rDNA sequences}

Based on its fragmented paroral membrane, Shazib et al. [4] separated Gruberia from the family Spirostomidae and established the new family Gruberiidae. This assignment is supported by the present phylogenetic analyses, in which Gruberia is clearly divergent from the family Spirostomidae. All sequences of Gruberia form a clade that is the sister-group of the Stentoridae + Blepharismidae + Folliculinidae + Maristentoridae + Fabreidae clade ('Clade SBFMF' in Fig. 8). This is consistent with the findings of previous studies [3-6, 39-41], and supports the scenario proposed by Luo et al. [39], which recognized that only species of 'Clade SBFMF' possess hypericin-like pigment granules. It is suggested that these pigment granules probably play important roles in the evolution of the class Heterotrichea, including the separation of Gruberia from 'Clade SBFMF' [3].

The genus Linostomella is most closely related to Condylostomides in the SSU rDNA tree which is consistent with the phylogenetic analyses in Rossi et al. [11]. The similarities of these two taxa in terms of habitat (freshwater), body shape (ellipsoidal), oral apparatus (conspicuous buccal cavity with adoral zone membrane on the left and paroral membrane on the right), contractile vacuole (present), and macronuclear shape (moniliform) $[22,42]$ support their close evolutionary relationship. The monophyletic family Condylostomatidae comprises two clearly separated sub-clades, namely Linostomella + Condylostomides and Condylostoma + Condylostentor + Chattonidium, which is broadly consistent with the findings of Rossi et al. [11]. We suspect that the separation of these sub-clades is probably related to differences in habitat, members of the former clade inhabiting freshwaters whereas members of the latter clade are marine.

The new sequence of Linostomella vorticella differs from the two unspecified Linostomella sequences (LN869952, LN870136) by 14 and 9 nucleotides respectively. This finding, combined with descriptions of populations that differ significantly in their morphology, suggests that the genus Linostomella may be not be monotypic.

\section{Conclusions}

In the present paper we describe two heterotrich ciliates, Gruberia foissneri spec. nov. and Linostomella vorticella, collected from Qingdao, China, using an integrative approach as suggested by Warren et al. [43]. Although G. foissneri spec. nov. closely resembles G. uninucleata, we provide evidence that these are separate species. In addition, an improved diagnosis of $L$. vorticella is supplied 
Table 3 Morphometric comparison of Linostomella vorticella populations with significant data and doubtful species reported under that name

\begin{tabular}{|c|c|c|c|c|c|c|c|c|}
\hline Body shape & $\begin{array}{l}\text { Body } \\
\text { length }\end{array}$ & $\begin{array}{l}\text { Body } \\
\text { width }\end{array}$ & $\begin{array}{l}\text { Peristome } \\
\text { length }^{\mathrm{a}}\end{array}$ & $\begin{array}{l}\text { Number of adoral } \\
\text { membranelles }\end{array}$ & $\begin{array}{l}\text { Number } \\
\text { of SK }\end{array}$ & $\begin{array}{l}\text { Number of } \\
\text { Ma nodules }\end{array}$ & Collection site & Reference \\
\hline $\begin{array}{l}\text { ellipsoidal and variable, } \\
\text { obliquely truncated at } \\
\text { the anterior end, a } \\
\text { depression at the } \\
\text { posterior end }\end{array}$ & $135-205$ & $70-110$ & $35-60 \%$ & $36-51$ & $37-51$ & $5-12$ & $\begin{array}{l}\text { A freshwater pond, } \\
\text { Qingdao, China }\end{array}$ & Present work \\
\hline $\begin{array}{l}\text { almost spherical body, } \\
\text { large and oblique oral } \\
\text { cavity in front }\end{array}$ & - & - & - & - & - & - & $\begin{array}{l}\text { A fire bucket, Berlin, } \\
\text { Germany }\end{array}$ & $\begin{array}{l}\text { Ehrenberg [7] } \\
\text { (type population) }\end{array}$ \\
\hline $\begin{array}{l}\text { ovoid body with a } \\
\text { broadly rounded rim }\end{array}$ & 210 & 160 & ca. $50 \%$ & - & - & 8 & $\begin{array}{l}\text { A polluted pond, } \\
\text { Warsaw, Poland }\end{array}$ & Wrześniowski [12] \\
\hline $\begin{array}{l}\text { ovoid body with broad } \\
\text { back and truncated } \\
\text { forward }\end{array}$ & 200 & - & ca. $50 \%$ & - & - & 5 & $\begin{array}{l}\text { Under water lilies, } \\
\text { Ariana, Tunisia }\end{array}$ & Penard [13] \\
\hline $\begin{array}{l}\text { globular, hemispherical } \\
\text { or ovoid body with } \\
\text { obliquely truncated } \\
\text { anterior }\end{array}$ & $100-125$ & - & ca. $45 \%^{\mathrm{b}}$ & - & - & - & - & Fauré-Fremiet [14] \\
\hline $\begin{array}{l}\text { bag-shaped, truncated } \\
\text { in front }\end{array}$ & $100-200$ & - & ca. $51 \%^{\mathrm{b}}$ & - & - & $6-10$ & $\begin{array}{l}\text { Clear pools and } \\
\text { ponds }\end{array}$ & Kahl [15] \\
\hline $\begin{array}{l}\text { ovoid body, large and } \\
\text { evenly rounded toward } \\
\text { the posterior extremity, } \\
\text { truncated at the anterior } \\
\text { end }\end{array}$ & 180 & 120 & ca. $50 \%$ & - & - & 5 & $\begin{array}{l}\text { Various ponds, } \\
\text { Nanjing, China }\end{array}$ & Wang \& Nie [16] \\
\hline- & - & - & ca. $47 \%^{\mathrm{b}}$ & - & $60-70$ & 11 & $\begin{array}{l}\text { Some ponds, } \\
\text { Hungary }\end{array}$ & Gelei $[17]^{+}$ \\
\hline- & 160 & - & ca. $56 \%^{\mathrm{b}}$ & $19-22$ & $31-34$ & $2-7$ & $\begin{array}{l}\text { A freshwater pond, } \\
\text { Mokolo, Cameroon }\end{array}$ & Dragesco $[18]^{\dagger}$ \\
\hline- & $140-170$ & $80-110$ & ca. $58 \%^{\mathrm{b}}$ & ca. 40 & $30-38$ & $8-12$ & $\begin{array}{l}\text { Kleikuhle, Husum, } \\
\text { Germany }\end{array}$ & Pätsch [19] \\
\hline $\begin{array}{l}\text { oval body, rounded } \\
\text { posteriorly }\end{array}$ & $140-170$ & - & - & ca .44 & $30-38$ & $2-12$ & - & $\begin{array}{l}\text { Dragesco \& Dragesco- } \\
\text { Kernéis [20] }\end{array}$ \\
\hline $\begin{array}{l}\text { bag-shaped, truncated } \\
\text { in front, rounded at } \\
\text { the back }\end{array}$ & $170-200$ & 100 & ca. $53 \%^{\mathrm{b}}$ & $40-50$ & $39-45$ & $5-9$ & $\begin{array}{l}\text { Meerfelder Maares, } \\
\text { Rheinland-Pfalz, } \\
\text { Germany }\end{array}$ & Packroff \& Wilbert [21] \\
\hline $\begin{array}{l}\text { saccular to ellipsoidal, } \\
\text { both ends broadly } \\
\text { rounded, ventral anterior } \\
\text { half obliquely truncated }\end{array}$ & $100-210$ & $70-160$ & ca. $50 \%$ & $40-50$ & $26-45$ & $2-15$ & $\begin{array}{l}\text { Eutrophic pond, } \\
\text { Salzburg, Austria }\end{array}$ & Foissner et al. [22] \\
\hline $\begin{array}{l}\text { ellipsoidal, rounded on } \\
\text { anterior and posterior } \\
\text { ends }\end{array}$ & $90-160$ & $70-120$ & ca. $50 \%$ & ca. 50 & ca. 35 & $8-12$ & $\begin{array}{l}\text { Aransas National } \\
\text { Wildlife Refuge, } \\
\text { Texas, the United } \\
\text { States }\end{array}$ & Alekperov et al. [23] ${ }^{\dagger}$ \\
\hline
\end{tabular}

Abbreviations: Ma Macronucleus; SK Somatic kineties

${ }^{\dagger}$ Doubtful species, ${ }^{a}$ Ratio of oral length to body length, ${ }^{b}$ Data from drawing or pictures, - Data not available

based on present and previous descriptions. Based on analyses of its morphology and molecular phylogeny, we posit that the genus Linostomella is not monotypic.

\section{Methods}

Sample collection, morphological methods, and identification

Gruberia foissneri spec. nov. was collected from the sandy surface of a seawater aquarium in the Laboratory of
Protozoology (N3603'45", E120¹9'52"), Qingdao, China, on 20th December 2018; the water temperature was $24{ }^{\circ} \mathrm{C}$ and salinity was $30 \mathrm{ppt}$ (Fig. 1c). Linostomella vorticella was isolated from a freshwater pond in Baihuayuan Park (N3603'53", E120'20'22"), Qingdao, China, on 5th January 2019; the water temperature was $2^{\circ} \mathrm{C}$ (Fig. 1d).

Living cells were randomly selected from the original samples and observed at 100-1000× magnification using both bright field and differential interference contrast 
microscopy (Olympus BX53; Zeiss AXIO Imager. D2). The protargol staining method of Wilbert [44] was used to reveal the infraciliature. The protargol powder was made according to Pan et al. [45]. The invertible function in Photoshop was used to adjust the photomicrographs of the infraciliature to show the structure more clearly. Hoechst 33342 solution was used to reveal the nuclear apparatus [46]. Counts, measurements, and drawings of stained specimens were made from photomicrographs (Nikon Y-IDT). Terminology and systematics are mainly according to Foissner et al. [22], Lynn [2] and Shazib et al. [4].

\section{DNA extraction, PCR amplification, and sequencing}

A single cell of each species was isolated from the original sample and washed five times with filtered habitat water to remove potential contaminants. Extraction of genomic DNA was performed using the DNeasy Blood \& Tissue Kit (QIAGEN, Hilden, Germany) following the manufacturer's instructions. Q5 ${ }^{\circ}$ Hot Start high-fidelity DNA polymerase (NEB, Ipswich, MA) was used to amplify the SSU rDNA using universal eukaryotic primers 82F (5'-GAAACTGCGAATGGCTC-3') and $18 \mathrm{~s}-\mathrm{R}$ (5'TGATCCTTCTGCAGGTTCACCTAC-3') [47, 48]. Cycling parameters of touchdown PCR were as follows: 1 cycle of initial denaturation at $98^{\circ} \mathrm{C}$ for $30 \mathrm{~s}$, followed by 18 cycles of amplification $\left(98^{\circ} \mathrm{C}, 10 \mathrm{~s} ; 69-51^{\circ} \mathrm{C}\right.$ touchdown, $30 \mathrm{~s} ; 72^{\circ} \mathrm{C}, 1 \mathrm{~min}$ ), and another 18 cycles $\left(98^{\circ} \mathrm{C}, 10 \mathrm{~s} ; 51^{\circ} \mathrm{C}, 30 \mathrm{~s} ; 72^{\circ} \mathrm{C}, 1 \mathrm{~min}\right)$, with a final extension of $72^{\circ} \mathrm{C}$ for $5 \mathrm{~min}$. PCR products were checked using agarose gel and were sequenced in TSINGKE (Qingdao, China). Sequence fragments were assembled into contigs using Seqman (DNAStar).

\section{Phylogenetic analyses}

A total of 96 taxa were used for phylogenetic analyses, including the two newly sequenced species and 94 sequences obtained from the GenBank database (see Fig. 8 for accession numbers). Five karyorelictean species were used as the outgroup. Sequences were aligned using MUSCLE on the web server GUIDANCE (http://guidance.tau.ac.il/ver2/) with default parameters [49]. Ambiguously aligned regions were excluded before phylogenetic analyses using G-blocks version $0.91 \mathrm{~b}[50,51]$. The final alignment with 1431 characters was used to construct phylogenetic trees. Maximum likelihood (ML) analysis was carried out on the CIPRES Science Gateway [52] using RAxMLHPC2 on XSEDE v8.2.12 [53]. Bayesian inference (BI) analysis was performed with MrBayes version 3.2.6 on XSEDE [54, 55] of the CIPRES Science Gateway. GTR+ I+ G was selected as the best fitting evolutionary model by MrModeltest version 2.2 according to the Akaike Information Criterion (AIC) [56]. Markov chain Monte Carlo simulations were then run with two sets of four chains using the default settings. The chain length for the analysis was 10,000,000 generations with trees sampled every 100 generations. The first $10 \%$ of trees were discarded as burn-in. MEGA 5.2 [57] was used to visualize tree topology.

\section{Abbreviations \\ Bl: Bayesian inference; CV: Coefficient of variation in \%; CV*: Contractile vacuole; FPM: Fragments of paroral membrane; M: Median; \\ Ma: Macronucleus; Max: Maximum; Mean: Arithmetic mean; Min: Minimum; ML: Maximum likelihood; n: Number of specimens; SD: Standard deviation; SK: Somatic kineties; SSU rDNA: Small subunit rDNA}

\section{Acknowledgements}

Not applicable.

\section{Authors' contributions}

$Y C$ performed the experiments and drafted the manuscript; $Y L$ performed the phylogenetic section; MM, QZ, AW and XC checked all the data and helped to write the manuscript; WS supervised and coordinated the work. All authors read and approved the final manuscript.

\section{Funding}

This work was supported by the Natural Science Foundation of China (No. 31970398 to XC; No. 31672251 to QZ) and the Marine S \& T Fund of

Shandong Province for Pilot National 457 Laboratory for Marine Science and Technology (Qingdao) (No. 2018SDKJ0406-1 to WS).

\section{Availability of data and materials}

All data generated or analysed during this study are included in the published article.

\section{Ethics approval and consent to participate}

Not applicable.

\section{Consent for publication}

Not applicable.

\section{Competing interests}

The authors declare that they have no competing interests.

\section{Author details}

${ }^{1}$ Institute of Evolution and Marine Biodiversity, and College of Fisheries, Ocean University of China, Qingdao 266003, China. ${ }^{2}$ Yantai Institute of Coastal Zone Research, Chinese Academy of Sciences, Yantai 264003, China. ${ }^{3}$ Center for Ocean Mega-Science, Chinese Academy of Sciences, 7 Nanhai Road, Qingdao 266071, China. ${ }^{4}$ Department of Life Sciences, Natural History Museum, London SW7 5BD, UK. ${ }^{5}$ School of Marine Sciences, Ningbo University, Ningbo 315211, China.

Received: 28 January 2020 Accepted: 25 June 2020

Published online: 02 October 2020

\section{References}

1. Gao F, Warren A, Zhang QQ, Gong J, Miao M, Sun P, et al. The all-databased evolutionary hypothesis of ciliated protists with a revised classification of the phylum Ciliophora (Eukaryota, Alveolata). Sci Rep. 2016; 6:24874.

2. Lynn DH. The ciliated Protozoa: characterization, classification, and guide to the literature. 3rd ed. German: Springer; 2008.

3. Fernandes NM, da Silva PT, da Silva-Neto ID, Schlegel M, Schrago CG. Expanded phylogenetic analyses of the class Heterotrichea (Ciliophora, Postciliodesmatophora) using five molecular markers and morphological data. Mol Phylogen Evol. 2016;95:229-46.

4. Shazib SUA, Vd'ačný P, Kim JH, Jang SW, Shin MK. Phylogenetic relationships of the ciliate class Heterotrichea (Protista, Ciliophora, Postciliodesmatophora) inferred from multiple molecular markers and multifaceted analysis strategy. Mol Phylogen Evol. 2014;78:118-35. 
5. Campello-Nunes PH, Fernandes NM, Szokoli F, Petroni G, da Silva-Neto ID. Morphology and phylogenetic position of Gruberia lanceolata (Gruber 1884) (Ciliophora, Heterotrichea) from Rio de Janeiro, Brazil. J Eukaryot Microbiol. 2018;65(6):902-12.

6. Chen XR, Shazib SUA, Kim JH, Kim MS, Shin MK. New contributions to Gruberia lanceolata (Gruber, 1884) Kahl, 1932 based on analyses of multiple populations and genes (Ciliophora, Heterotrichea, Gruberiidae). Eur J Protistol. 2018;65:16-30.

7. Ehrenberg CG. Dritter Beitrag zur Erkenntniss grosser Organisation in der Richtung des kleinsten Raumes. Berlin: Akademie der Wissenschaften; 1833.

8. Dujardin F. Histoire naturelle des zoophytes. Infusoires, comprenant la physiologie et la classification de ces animaux et la maniére de les étudier à I'aide du microscope. Paris: Librairie Encyclopédique de Roret; 1841.

9. Jankowski AW. Revision of a system of class Polyhymenophora (Spirotricha). Tezisky Dokl Zool Inst Akad Nauk SSSR. 1978:39-40.

10. Aescht E. Catalogue of the generic names of ciliates (Protozoa, Ciliophora) Denisia. 2001;1:1-350.

11. Rossi A, Boscaro V, Carducci D, Serra V, Modeo L, Verni F, et al. Ciliate communities and hidden biodiversity in freshwater biotopes of the Pistoia province (Tuscany, Italy). Eur J Protistol. 2016;53:11-9.

12. Wrześniowski A. Beobachtungen über Infusorien aus der Umgebung von Warschau. Z Wiss Zool. 1870;20:467-511.

13. Penard E. Études sur les Infusoires d'Eau Douce. Genève: Georg \& Cie; 1922.

14. Fauré-Fremiet E. Contribution a la connaissance des infusoires planktoniques. Bull Biol Fr Belg. 1924;6:1-171.

15. Kahl A. Urtiere oder Protozoa. I: wimpertiere oder Ciliata (Infusoria) 3. Spirotricha. Tierwelt Dtl. 1932;25:399-650.

16. Wang CC, Nie D. Report on the rare and new species of fresh water infusoria, part 1. Contr Biol Lab Sc Soc China. 1933;10:1-99.

17. Gelei J. Über die Lebensgemeinschaft einiger temporärer Tümpel auf einer Bergwiese im Börzsönygebirge (Oberungarn) III. Ciliaten. Acta Biol Hung. 1954:5:259-343.

18. Dragesco J. Cilliés Libres Du Cameroun. Cameroun: Annales de La Faculté des Sciences; 1970.

19. Pätsch B. Die Aufwuchsciliaten des Naturlehrparks Haus Wildenrath: Monographische Bearbeitung der Morphologie und Ökologie. Bonn: Arbeiten aus dem Institut für Landwirtschaftliche Zoologie und Bienenkunde; 1974.

20. Dragesco J, Dragesco-Kernéis A. Ciliés libres de l'Afrique intertropicale: introduction à la connaissance et à l'étude des Ciliés. Paris: Faune Tropicale (Éditions de I'ORSTOM); 1986.

21. Packroff G, Wilbert N. Taxonomische Studien über die Ciliatenfauna (Protozoa, Ciliophora) der Eifelmaare. Arch Protistenkd. 1991;140(2-3):12139.

22. Foissner W, Berger $H$, Schaumburg J. Identification and ecology of limnetic plankton ciliates, vol. 3/99. Munich: Informationsberichte des Bayerischen Landesamtes für Wasserwirtschaft; 1999.

23. Alekperov I, Buskey E, Snegovaya N. The free-living ciliates of the Mexican gulf coast near Port Aransas city and its suburbs (South Texas, USA). Protistology. 2007:5(2-3):101-30.

24. Ehrenberg CG. Die Infusionsthierchen als vollkommene Organismen: Ein Blick in das tiefere organische Leben der Natur. Leipzig: Verlag von Leopold Voss; 1838.

25. Tuffrau M. Les structures fibrillaires somatiques et buccales chez les ciliés hétérotriches. Protistologica. 1968;3(1):369-94.

26. Foissner W, Berger H, Kohmann F. Taxonomische und ökologische Revision der Ciliaten des Saprobiensystems. Bandll: Peritrichia, Heterotrichida, Odontostomatida, vol. 5/92. Munich: Informationsberichte des Bayer Landesamtes für Wasserwirtschaft; 1992

27. Chen XR, Kim JH, Shazib SUA, Kwon CB, Shin MK. Morphology and molecular phylogeny of three heterotrichid species (Ciliophora, Heterotrichea), including a new species of Anigsteinia. Eur J Protistol. 2017; 61:278-93.

28. Beltran E. Gruberia calkinsi sp. nov., a brackish-water ciliate (Protozoa, Heterotrichida) from woods hole, Massachusetts. Biol Bull. 1933;64(1):21-7.

29. Dragesco J. Ciliés mésopsammiques littoraux: systématique, morphologie, écologie. Roscoff: Des Travaux de la Station Biologique; 1960.

30. Gruber A. Die Protozoen des Hafens von Genua. Halle: E. Blochmann \& Sohn; 1884.

31. Lepsi J. Protozoologie. România, Bucarest: Academia Republicii Socialiste; 1965.
32. Ozaki Y, Yagiu R. Studies on the marine ciliates of Japan, mainly from the Setonaikai (the Inland Sea of Japan). J Sci Hirosima Univ Ser B. 1941;8:16584

33. Dragesco J. Infraciliature de quinze especes de cilies mesopsammiques marins comprenant Trachelocerca stephani comb. nova, T. bodiani comb. nova, Tracheloraphis filiformis spec. nova, T. exilis spec. nova, et Sathrophilus arenicolus spec. nova. Linzer Boil Beitr. 2002;34(2):1545-626.

34. Dragesco J. Ciliés mésopsammiques d'Afrique noire. Paris: Cahiers de Biologie Marine; 1965

35. Hu XZ, Lin XF, Song WB. Ciliate atlas: species found in the South China Sea. Beijing: Science Press; 2019.

36. Rosati G, Modeo L, Melai M, Petroni G, Verni F. A multidisciplinary approach to describe protists: a morphological, ultrastructural, and molecular study on Peritromus kahli Villeneuve-Brachon, 1940 (Ciliophora, Heterotrichea). J Eukaryot Microbiol. 2004;51(1):49-59.

37. Song WB, Warren A, Hu XZ. Free-living ciliates in the Bohai and yellow seas, China. Beijing: Science Press; 2009.

38. Yan Y, Chen XM, Chen XR, Gao F, Al-Farraj SA, Al-Rasheid KAS. Morphology and molecular phylogeny of three marine Condylostoma species from China, including two new ones (Ciliophora, Heterotrichea). Eur J Protistol. 2015;51(1):66-78.

39. Luo J, Ma MZ, Lu BR, Li XH, Warren A, Shi YH, et al. The taxonomy and phylogeny of the poorly known heterotrich ciliate Ampullofolliculina lageniformis Hadži, 1951 (Ciliophora: Heterotrichea). J Eukaryot Microbiol. 2019;66(6):925-36.

40. Yan Y, Fan Y, Chen XR, Li LF, Warren A, Al-Farraj SA, et al. Taxonomy and phylogeny of three heterotrich ciliates (Protozoa, Ciliophora), with description of a new Blepharisma species. Zool J Linnean Soc. 2016;177(2): 320-34.

41. Chi Y, Duan LL, Luo XT, Cheng T, Warren A, Huang JA, et al. A new contribution to the taxonomy and molecular phylogeny of three, wellknown freshwater species of the ciliate genus Spirostomum (Protozoa: Ciliophora: Heterotrichea). Zool J Linnean Soc. 2020;189:158-77.

42. Foissner W, Agatha S, Berger H. Soil ciliates (Protozoa, Ciliophora) from Namibia (Southwest Africa), with emphasis on two contrasting environments, the Etosha region and the Namib Desert. Denisia. 2002;5:11459 .

43. Warren A, Patterson DJ, Dunthorn M, Clamp JC, Achilles-Day UE, Aescht E, et al. Beyond the "code": a guide to the description and documentation of biodiversity in ciliated protists (Alveolata, Ciliophora). J Eukaryot Microbiol. 2017;64(4):539-54.

44. Wilbert N. Eine verbesserte Technik der Protargolimprägnation für Ciliaten. Mikrokosmos. 1975:64:171-9.

45. Pan XM, Bourland WA, Song WB. Protargol synthesis: an in-house protocol. J Eukaryot Microbiol. 2013;60(6):609-14.

46. Jiang $Y H$, Zhang $\Pi$, Vallesi A, Yang $X Y$, Gao F. Time-course analysis of nuclear events during conjugation in the marine ciliate Euplotes vannus and comparison with other ciliates (Protozoa, Ciliophora). Cell Cycle. 2019;18(3): 288-98.

47. Jerome CA, Simon EM, Lynn DH. Description of Tetrahymena empidokyrea $\mathrm{n}$. sp., a new species in the Tetrahymena pyriformis sibling species complex (Ciliophora, Oligohymenophorea), and an assessment of its phylogenetic position using small-subunit rRNA sequences. Can J Zool. 1996;74(10):1898906.

48. Medlin L, Elwood HJ, Stickel S, Sogin ML. The characterization of enzymatically amplified eukaryotic 16S-like rRNA-coding regions. Gene. 1988;71(2):491-9.

49. Wang CD, Zhang $\Pi$, Wang YR, Katz LA, Gao F, Song WB. Disentangling sources of variation in SSU rDNA sequences from single cell analyses of ciliates: impact of copy number variation and experimental error. P Roy Soc B: Biol Sci. 2017;284(1859):20170425.

50. Castresana J. Selection of conserved blocks from multiple alignments for their use in phylogenetic analysis. Mol Biol Evol. 2000;17(4):540-52.

51. Talavera G, Castresana J. Improvement of phylogenies after removing divergent and ambiguously aligned blocks from protein sequence alignments. Syst Biol. 2007;56(4):564-77.

52. Miller MA, Pfeiffer W, Schwartz T. Creating the CIPRES science gateway for inference of large phylogenetic trees. In: Gateway Computing Environments Workshop; New Orleans. 2010: 1-8.

53. Stamatakis A. RAxML version 8: a tool for phylogenetic analysis and postanalysis of large phylogenies. Bioinformatics. 2014;30(9):1312-3. 
54. Ronquist F, Teslenko M, van Der Mark P, Ayres DL, Darling A, Höhna S, et al. MrBayes 3.2: efficient Bayesian phylogenetic inference and model choice across a large model space. Syst Biol. 2012;61(3):539-42.

55. Wang $Y R$, Wang $C D$, Jiang $Y H$, Katz LA, Gao F, Yan Y. Further analyses of variation of ribosome DNA copy number and polymorphism in ciliates provide insights relevant to studies of both molecular ecology and phylogeny. Sci China Life Sci. 2019;62(2):203-14.

56. Nylander JAA. MrModeltest ver. 2. 2004:evolutionary biology Centre, Uppsala University, Sweden.

57. Tamura K, Peterson D, Peterson N, Stecher G, Nei M, Kumar S. MEGA5: molecular evolutionary genetics analysis using maximum likelihood, evolutionary distance, and maximum parsimony methods. Mol Biol Evol. 2011;28(10):2731-9.

\section{Publisher's Note}

Springer Nature remains neutral with regard to jurisdictional claims in published maps and institutional affiliations.

Ready to submit your research? Choose BMC and benefit from:

- fast, convenient online submission

- thorough peer review by experienced researchers in your field

- rapid publication on acceptance

- support for research data, including large and complex data types

- gold Open Access which fosters wider collaboration and increased citations

- maximum visibility for your research: over $100 \mathrm{M}$ website views per year

At $\mathrm{BMC}$, research is always in progress.

Learn more biomedcentral.com/submissions 